\title{
The Importance of Management Control Systems (MCS) in Small and Medium Enterprises (SME), An Empirical Literature Review
}

\author{
Bienmali Kombate ${ }^{1^{*}}$ \\ ${ }^{1}$ Sebelas Maret University, Surakarta, Indonesia
}

\begin{abstract}
The main focus in this paper is the importance of Management Control Systems (MCS) in Small and Medium Enterprises (SMEs). The research is based on empirical literature by collecting and interpreting researchers finding on the important role that play MCS in SMEs. A greater control systems implementation can createladded a value and influencing stakeholders to practice concrete actions to reduce costs derived from the exploitation in SMEs.
\end{abstract}

Keywords: Management Control Systems, Small and Medium Enterprises

\section{INTRODUCTION}

MCS is the fundamental major in any business activities therefore, several study are shown that in SME entrepreneurship development is a viable means of promoting self reliance in economic development as well as accelerating the pace of industrial and technological progress through the promotion of small and medium enterprises and encouraging entrepreneurial spirit and skills in these business ventures (Dekeng, 2014). SMEs development has generally been discussed from the perspective of poverty, under employment, diversification in economy, rural/urban imbalance, regional dispersion of industrial growth and long term contribution which entrepreneurship in small and medium enterprises can make in resolving and eliminating some of these problems (Sule, 1996; Nnamma, 2001; Essien, 2001). In recent years research in MCS confirmed that there has been a growing interest in the relationship with MCS in SMEs. Some authors suggested that MCS should be tailored explicitly to support the strategy of the SME which can lead business to competitive advantage and superior performance (Dent, 1990; Samson et al., 1991; Simons, 1987a, 1990). Also, there is evidence that greater SME organizational performance may result from a matching with its external organization's strategy and internal structures and systems (Govindarajan \& Gupta, 1985; Govindarajan, 1988. Today, there is evidence that SMEs are on the pressure to ensusre the effective internal control as a part of the Corporate Governance initiatives (Wiliam and David B, 2004).

The world bank, International accounting standards, the globalization of economy, the complexity of business and allegations of fraudulent financial reporting, all have recently sharpened the ever-increasing attention on SMEs internal controls and internal auditing. Simultaneously, the capital markets have

* Corresponding author. Email address: bienmalikombate@ student.uns.ac.id 
seen many new financial instruments and players being introduced, making the transactions and operations more complex. In this context, SME internal control is to be carried out on the basis of standing laws and regulations, which generally include also the policies and decrees of state as well as rules and by-laws of enterprise. Within this framework of extremely fluid SMEs business environment and the used and importance of MCS, the purpose of this paper is to highlight the importance of a well organized MCS SMEs for ensuring the well being of SMEs operations, the safe and soundness of a saving and credit institution's activity, and by this the stability of the banking system as a whole. According to up-to-date theoretical and empirical literature, the results point out that all components of internal audit is vital in the effectiveness of internal control and consequently in the business survival and success.(Karagiorgos et al,: 2009).

\section{SMALL AND MEDIUM ENTERPRISES (SMEs) OWNERSHIP AND SOURCE OF FINANCE}

The definition of Small and Medium Enterprises varies according to the author or to the country or the economy organization by the size of their employees, turnover/total balance sheet and ownership. Basing on ownership, nowadays in European Union economy, SMEs to remain driving the innovation and competitive in the market are operating as multinational corporate while in developing countries SMEs still on empirical definition field where SMEs partner are often single ownership or family ownership which sometimes with these limitation make SMEs in developing countries facing some challenges for financial resources finding and not trustworthy by its stakeholders.

Many European investors put their interest to invest in SMEs because of its limited to a certain size where it is easier to get an overview over it, it is easier to manage and more flexible. The word bank (43) in recent years comes up to help Small and Medium Enterprises (SMEs) which play a major role of economy development in most nations, particularly in developing countries. According to word bank publication, Formal SMEs contribute up to 45 percent of total employment and up to 33 percent of national income (GDP) in emerging economies. These numbers are significantly higher when informal SMEs are included. According to estimates, 600 million jobs will be needed in the next 15 years to absorb the growing global workforce, mainly in Asia and Sub-Saharan Africa. In emerging markets, most formal jobs are with SMEs, which also create 4 out of 5 new positions. However, access to finance is a key constraint to SME growth; without it, many SMEs languish and stagnate.

SMEs are less likely to be able to secure bank loans than large firms; instead, they rely on internal or "personal" funds to launch and initially run their enterprises. Fifty percent of formal SMEs don't have access to formal credit. The financing gap is even larger when micro and informal enterprises are taken into account. Overall, approximately 70 percent of all MSMEs in emerging markets lack access to credit. While the gap varies considerably between regions, it's particularly wide in Africa and Asia. The current credit gap for formal SMEs is estimated to be 
US\$1.2 trillion; the total credit gap for both formal and informal SMEs is as high as US\$2.6 trillion.

A World Bank Group study suggests (43) there are between 365- 445 million micro, small and medium enterprises (MSMEs) in emerging markets: 25-30 million are formal SMEs; 55-70 million are formal micro enterprises; and 285-345 million are informal enterprises. Moving informal SMEs into the formal sector can have considerable advantages for the SME (for example, better access to credit and government services) and to the overall economy (for example, higher tax revenues, better regulation). Also, improving SMEs' access to finance and finding solutions to unlock sources of capital is crucial to enable this potentially dynamic sector to grow and provide the needed jobs.

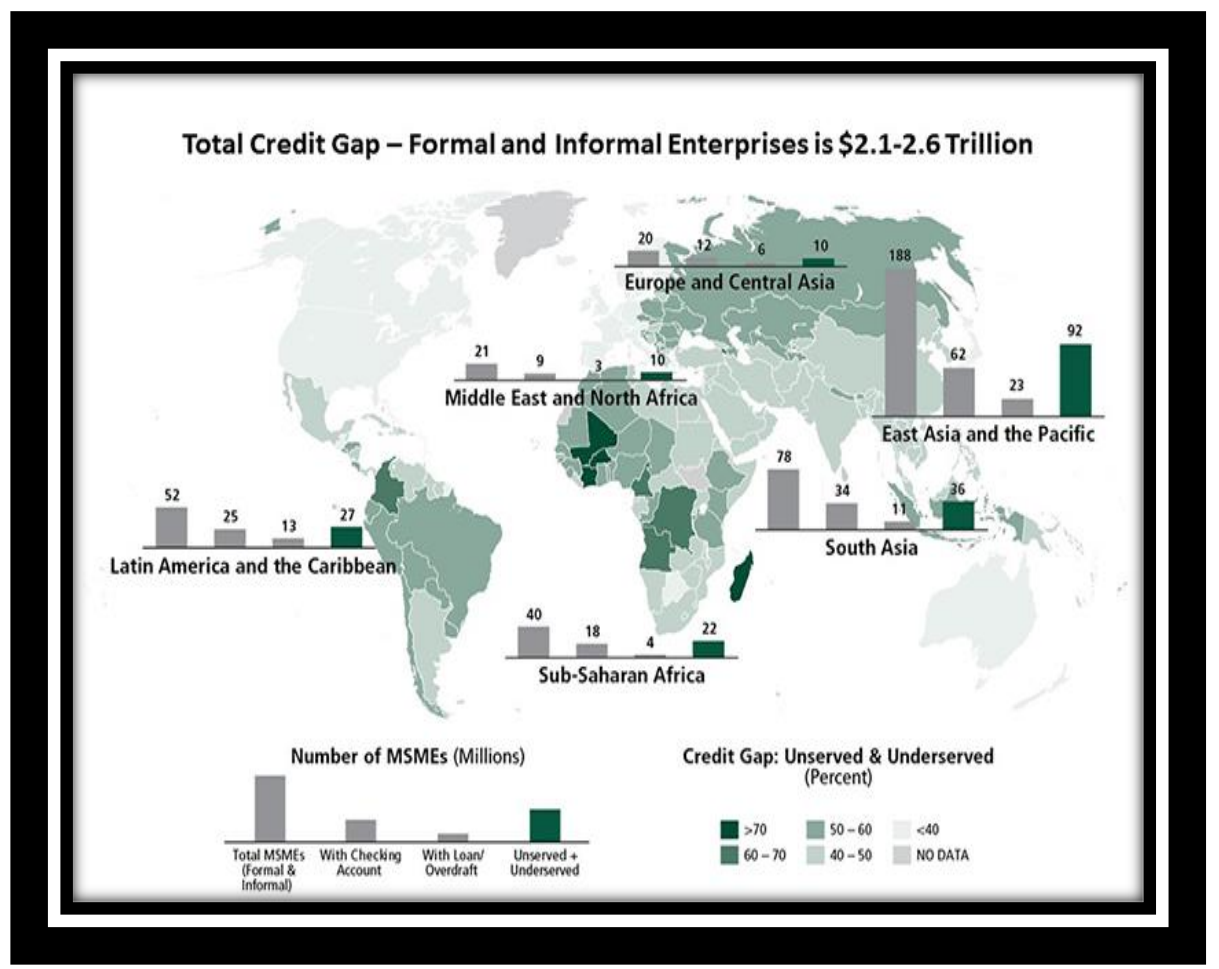

http://www.worldbank.org/en/topic/financialsector/brief/smes-finance (43)

To help improve SMEs to finance and find innovative solutions to unlock sources of capital the World Bank Group's work on the key access approach including holistic, combining advisory and lending services to clients to increase the contribution that SMEs can make to the economy. Was cited some advisory Support for Financial Sector Infrastructure:

a. Credit Reporting Systems are important as better credit information can lead to increased credit for SMEs. 
b. Secured Transaction Registries ensure that SMEs can provide moveable collateral as the basis for more lending.

c. Modernized Insolvency Regimes can help restructure viable businesses while also promoting the efficient and effective "exit" of those firms that are not economically efficient.

d. Streamlining of Payments Systems supports the more efficient movement of money throughout the economy, including G2B, B2B, remittances and other payments.

In recent years, the word bank increasingly looking to develop more innovative forms of SME financing, including: an extension of early stage innovation financing delivery mechanisms; franchising models; digital finance solutions; crowd funding; P2P financing; and Big Data Solutions. Important few results of this work in the SMEs Finance space are:

a. Lines of Credit: In 2011 post the revolutions, countries in the Middle East and Africa region requested funding for SMEs to support private sector growth and employment generation. Around one billion dollars have subsequently been lent to Egypt, Tunisia, Morocco, Jordan and Lebanon. This has helped restore private sector funding in economies where severe budgetary strains have crowded out the private sector particularly the more marginal SME sector. It is estimated that these loans have directly created around 150,000 jobs over the past four years.

b. Secured Transactions Reform. Between October 2007 and June 2011 the secured transactions reform work supported by the WBG in China cumulatively facilitated US\$3.58 trillion accounts receivable financing, of which US\$1.09 trillion went to SMEs. As a result of the reform the total number of commercial loans involving movable assets grew by $21 \%$ per year over 2008-2010, versus a flat rate over the period 2006-2008.

c. In Colombia, in less than one year more than 100,000 loans secured with movable assets have been registered in the movable collateral registry, of which 5,000 were for SMEs for an aggregate amount of US\$3.43 billion (compared to a few hundred per year before the reform).

d. Liberia started a collateral registry in 2014 to securitize movable assets, making it possible for farmers and entrepreneurs to use such assets against which they could borrow money. In less than a year since its launch - most of which was during the Ebola crisis - US\$227 million in loans were registered.

e. In Afghanistan, the recent establishment of the Public Credit Registry to determine the credit performance of borrowers has significantly improved access to financing of small and medium enterprises. 


\section{IMPORTANCE OF MANAGEMENT CONTROL SYSTEMS IN SMES}

Management control was defined by Anthony (1965) as "the process by which managers ensure that resources are obtained and used effectively and efficiently in the accomplishment of the organization's objectives." This definition limited subsequent researchers not only to envisage MCS as encompassing the largely accounting-based controls of planning, monitoring of activities, measuring performance and integrative mechanisms, it also served to artificially separate management control from strategic control and operational control. MCS have also been described as processes for influencing behavior (Flamholtz et al., 1985). MCS provide a means for gaining cooperation among collectives of individuals or organizational units who may share only partially congruent objectives, and channeling those efforts toward a specified set of organizational goals (Ouchi, 1979; Flamholtz, 1983). Controls have been categorized in many ways. For example, formal and informal controls (Anthony et al., 1989) output and behavior controls (Ouchi, 1977) market, bureaucracy and clan controls (Ouchi, 1979) administrative and social controls (Hopwood, 1976) and results, action and personnel controls (Merchant, 1985a). A brief discussion of these classifications will illustrate the breadth of controls used in research.

A formal Management Control System (MCS) includes rules, standard operating procedures and budgeting systems. These are the more visible, objective components of the control system, and thus, the easiest to research. Empirical research that studies MCS and strategy has focused primarily on formal controls. These include output or results controls which are of a feedback nature, and often financially oriented. They include controls that aim to ensure that specific outcomes will be achieved and involve monitoring, measuring and taking corrective actions. Controls that focus on feed forward control (ex-anti controls) include administrative controls (standard operating procedures and rules), personnel controls (human resource management policies) and behavior controls (the ongoing monitoring of activities and decisions). Informal controls are not consciously designed. They include the unwritten policies of the organization and often derive from, or are an artifact of the organizational culture.

Ouchi (1979) described clan controls that derive from the shared values and norms, or the culture of the organization. 1 usually clan controls are Informal, rather than formal controls, however, some formal controls also derive from the organizational culture. For example, the formal organizational mission or objectives may reflect the values and beliefs of the dominant culture. Informal controls are important aspects of MCS and the effectiveness of formal controls may be dependent on the nature of the informal controls that are also in place (Otley, 1980; Flamholtz, 1983). While these conventional definitions of MCS may have been adequate in the past, it has been argued that they need to be reviewed to accommodate the changed business conditions of the 1990s (Otley, 1994). For example, the role of MCS in the formation and implementation of strategy is becoming of greater interest in both academic and professional management journals, so our understandings of MCS may need to be broadened to encompass these areas. More recently, Gold and Quinn (1990) described strategic controls, 
which are concerned with formulating competitive benchmarks and using nonfinancial performance measures to develop short-term performance Indicators that are explicitly linked to achievement of long-term strategic goals.

The emphasis on senior management that has dominated MCS research is becoming less relevant with an increasing interest in employee empowerment (Otley, 1994; Simons, 1995). Many believe that it is becoming more common for lower level employees to be actively involved, not only in the day-today processes that were once the domain of middle and senior managers, but in activities that are of strategic significance. Thus, the artificial boundaries between operational, managerial and strategic control, as initially described by Anthony (1965) may no longer hold. In the light of these concerns it is apparent that the orientation towards accounting controls and accounting information, which has dominated much of the MCS research, is not sufficiently broad to capture more modern approaches to effective control (Emmanuel et al., 1990)

The dynamic nature of MCS and its potential role in strategic change is an area of increasing interest (Simons, 1990; Dent, 1990). Basic concepts and frameworks developed in the strategy literature during the past two decades have not always been widely adopted in these studies and the multidimensional nature of strategy is seldom recognized (Govindarajan \& Gupta, 1985, is an exception). These problems can lead to under-specification or a misspecification of the research design which can affect the integrity of research findings.

SMEs managers are responsible for fixing an effective control which match with the environment in their organizations. This is a part of their stewardship responsibility over the use of resources. Indeed, the tone managers set through their actions, policies, and communications can result in a culture of either positive or lax control. Planning, implementing, supervising, and monitoring are the most important fundamental components MCS especially in internal control. There is evidence that the SME business subsector is characterized by high rate of failure that could be reduced if the businesses were properly managed. A frequently mentioned specific shortcoming of many SME business managers is the failure to put in place effective financial control tools that guarantee meaningful organization performance (Nwankwo et al, 2012). Most researches have shown that good control leads to greater organizational effectiveness (Glueck, 1981; Donnely et.al, 1995; Jasra et al, 2011). In fact, Memba (2012) rationalize the need for control in organizations' desired performance as he opines that given that we live in an imperfect world where plans do not always work, control becomes necessary. This is predicated upon the incessant changes in our business environment which often alter organizational plans. Again, since organizations deal with different categories of employees who may not be so motivated to achieve set plans and objectives, it becomes imperative that control measures are infused in business plans and activities to achieve desired performance.

Management control is a significant component of economic and social reality through which managers have the possibility of dynamic information, real preventive findings raise the value and quality of decisions and ensures the smooth functioning of enterprises. Management control, as part of the economic 
information system, is a key factor in the operation, development and enterprise development, if it's well organized at all levels and organizational structures that exist within it.

Control is a management tool for finding such violations, and knowledge of reality and the possibilities for identification and prevention of failures and anomalies. Effective management control helps managers in the company, discovers and informs the negative aspects when they are manifested as a tendency and intervenes operatively for preventing and eliminating the causes that led to their occurrence. In the literature the definition and interpretation of management control was done differently from one author to another and / or from one country to another. In the opinion of some authors may be associated with management control on the one hand the idea that surveillance of checking the way that things are conducted in accordance with what is desired or the other is associated with the concept of power, authority, namely the knowledge and easily overcome any difficult situation. Viewed from this perspective, management control is defined as "all processes of reception and use of information which aims to oversee and coordinate development at all levels within the organization". This point of view shows how management control is exercised at all levels of the organization and it is broadcast everywhere where an activity is performed. In view of other authors (R.S. Kaplan, 1984), management control was born from the need to understand the complexity and faculty to organize space and time provided by the proposed development H. Bouquin (1994).

Since 1994, H. Bouquin consider management control as "a set of processes and devices which guide the actions and behavior in organizations, to make them consistent with the medium and long term objectives and builds on information systems. Their purpose related to the organization and enterprise performance, where possible, to identify its causes and measurement" H. Bouquin (2008). H. Bouquin (2008) believes that management control gives managers the opportunity "to dominate the organization that they are managing positively, particularly by targeting the actions of those whose autonomy and delegate who is directing care staff: managers. Management control systems (MCS) should outline to guide SMEs management decision-making and behavior by coordinating the processes of planning and control.

MCS should be aligned with the SMEs organization's strategies and goals and fit with its organization's structure and decision-making format. Control systems are often used in conjunction with performance measurement systems, and good SMEs control system should used information from both internal and external the organization. The mains focus objectives of MCS in SMEs to improve and make a good soundness of the control is to gather information both formally and informally; inside although outside the company's among:

a. accounting system, for information relating to revenues and expenses

b. Human resources system, for information on payroll, absenteeism, and benefits, and

c. quality-control systems, for information on defects, rework, and so on. 
Management control in SMEs is defined to acts as an ongoing process and organized to take place before, during and after the action" Bouquin H. (2008). Prof. C. Iacob considers management control as the whole process of information collection and use, aiming to "monitoring and verification of progress at all levels within the company" Iacob C. (1999). But if we refer to the traditional management control then we need to understand a control process based on three main phases: identification of facilities that are to be achieved, defining the tasks and resources, and compare the results obtained with the expected results. Traditional management control often in used in SMEs is based principally on the financial statements such as balance sheet, results, notes, analytical accounts, but also providing historical information on the results of the work done by a company and have no ability to identify the causes of action variables these results. Later, watching from a practical perspective, management control often takes the form of "control the budget" by finding the differences between expected and realized levels and calculation of factors of influence, which is in fact the core business management controllers. In this control concept is assigned the role of "an instrument of policy the company forecast.

Although the small and medium enterprises (SMEs), management control, are less formalized, it is assured a manager with accounting firm with a triple meaning: self-control (internal control), control for others (external control) and control for the state (public control). Management control, conducted in the conditions of market economy, for small and medium enterprises appears as a regulatory tool, the mechanism contributing to the integration of the company in the market economy through a complex and ongoing managerial activity.

Management control is presented:

a. Knowledge as a process of economic and financial situation of the company;

b. As a practice, because it is an activity carried out by competent persons who use specific techniques and methods and an organized system of information;

c. As a means of study and action for internal users;

d. As a factor for both security and enterprise management authority and society.

Control exercised in the management of SMEs appears as a tool that provides an accurate picture, a comprehensive vision of their knowledge of the actual situation and to consider allowing prospects. Over time, the occurrence of technical factors, economic, social, and economic developments that have influenced changes in attitude to work of employees, control has evolved and it was redefining the traditional concept of control of an undertaking within the meaning of "action seeking to dominate or even influence a system". In this sense, P. Boisselier organizational control defines as "a process that, before carrying out the action direct, that during the action - adjust, and after completion of action evaluate its results to draw conclusions" Boisselier P. (1999) and provides for them a set of mechanisms designed to ensure the quality of decisions and actions. 


\section{FINANCIAL CONTROL PRATICES AMONG SMES IN EMPIRICAL EVIDENCE}

The question concerns the possible development of creative management control is the main focus research in MCS. A research hold in Nigerian confirmed that SMEs are evidently aware of financial control system (Melodi, 1995). A survey of inventory control practices according to Melodi (1995) reveals that participating firms have knowledge of modern inventory systems or policies but have not appreciated the application of modern tools of making inventory decisions beneficial to their businesses. Nevertheless, this shows that some of among SMEs are not just at the ready state to use the modern inventory planning systems but the SMEs have the tools that are founded on operation's research/management science techniques of which mostly are application of mathematical models with added advantage of programmed decision as practiced in the industrialized countries from which the technology used was borrowed.

Nyakundi et al (2014) study on management practices in Nigerian private companies indicates that Nigerian firms use some financial control techniques occasionally. Similarly, an attempt to examine the degree of fit between size and structural variables in small and medium enterprises also recommend increase in the use of control measures to achieve high economic performance in these enterprises (Siwangaza et al, 2014). Meanwhile, it should be noted that financial control in large organizations is the responsibility of different groups of managers such as audit committee, management committee, executive committee, chief accountants, financial controller, purchasing manager, and credit manager to mention just a few. The situation is usually different in small and medium enterprises. All stages and levels of financial control are likely to be the responsibility of a single manager; often times, the owner or at least the manager who typically does much of the work rather than assigning it to other managers (Memba, 2011). This decreases the need for coordination and control but requires the small business manager to understand and perform a wide variety of activities.

\section{THE USED OF ACCOUNTING IN MANAGEMENT CONTROL SYSTEM (MCS)}

In Control System, the accounting profession has been defined as the backbone of organization societal life. This is because SMEs organizations use accounting information for planning and controlling their activities and also to report the results of these activities to the stakeholders including creditors, labor unions and government agencies. Likewise, non- profit organizations such as churches, town unions, social association and clubs also use accounting information for planning, conducting and reporting their activities. The Federal, State, Local Governments and other government agencies use accounting information in similar ways. According to Adegite (2010) the accounting profession speaks the language of business as it records all transactions of organizations that have monetary implications. Thus accounting is that discipline that involves the systematic gathering, classification, recording, analysis, interpretation and transmission of information to assist users make economic 
decision. Control System in accounting profession according to Evbodahe (2009) is the responsibility to spread financial knowledge and for a commitment to help SMEs organizations to develop their capacity to success.

At the global level, International Financial Reporting Standards (IFRS) has helped many SMEs in developing countries to build stronger and more stable economies. In fact the profession is empowered by investor confidence and public trust without which the credibility of the information prepared and presented by the management in SMEs organization will be at risk. In Indonesia, to insure an ethical sound in SMEs though big enterprises, in publics or privates sectors, Institute of Indonesia Chartered Accountants. Ikatan Akuntan Indonesia (IAI) guide accounting practice in control system by devoted to such to Management Control System (MCS) issues as integrity, transparency and accountability.

In Management Control System, accounting skills is define as the totally of skills ranging from record keeping, attention directing, financial management and reporting skills that are expected to promote effective decision, performance evaluation and business reporting of SMEs, (Akande 2011). Furthermore, Akande insisted that in SMEs, attention on directing skill should enables the owner manager of SME to make vital decision on production and pricing issues while reporting skill describes the method, and technique by which business information are reported to the stakeholders of the organization. According to the Accounting Education Change Commission (AECC 1990) to be successful in their careers, accounting graduates need skills and abilities that beyond accounting technical knowledge, they include communication skills, analytical skills and interpersonal skills. Accounting graduates are also expected to be able to receive and send information, identify and solve unstructured problems in unfamiliar settings and exercise judgment, Agbiogwu (2010) highlighted nine (9) common traits to SMEs manager in control system besides accounting skills including:

1. Physical and mental stamina

2. A desire to take control of their own destiny

3. A competitive instinct

4. Resilience in the face of defeat

5. Good Judgment

6. Decisiveness

7. The ability to inspire others

8. An unfailing positive attitude

9. Great communication skills.

\section{CREATIVE A GREATER SOUNDNESS OF MCS IN SMES TO BOOST BUSINESS ACTIVITIES}

It is noted that compliance with the thresholds on the number of employees is mandatory when the following two criteria are optional for the recognition and classification of businesses in the SMEs (SMEs can choose a year or turnover criterion, or one relating to total assets). From this point of view it ensures equal treatment to all SMEs, regardless of the economic activity type that are connected to. Identifying SMEs taking into account the criteria mentioned above and 
considering that economic activity is the determining factor and not the legal form of company can achieve harmonization of national measures with the EU at least on regional development and seeking funding. In Romania, the definition and delimitation of SMEs is different from the European Union, although it keeps all the criteria on the number of employees and turnover. There are differences in the approach of SMEs linked to total assets and scope of their activities (in Romania, do not fall into the category of SMEs, the banks, insurance companies and reinsurance, financial management companies of investment funds, security firms and companies with exclusive foreign trade activity). However, if we follow the article 103 of the Tax Code, valid for 2008, we see a definition of micro enterprises in the spirit of European law, which is represented by a Romanian legal person that meets the following conditions, on 31 December of the previous fiscal year:

a. Has entered the objects of production of goods, services, and / or trade;

b. Has from 1 to 9 employees, including;

c. Achieved revenues did not exceed the equivalent in RON of 100.000 euro;

d. The legal entity's capital is held by persons other than the State, local authorities and public institutions.

At the same time we must remember the important role of SMEs in the economic system:

a. SMEs contribute to the social stability of the region or geographical area where their work as creating jobs;

b. Help greatly to increase the competitiveness of markets because even SMEs are sources of competition;

c. Participate in economic growth, contributing actively to the creation of supply of goods and services, namely the GDP, increase exports and domestic investment;

d. SMEs show a greater flexibility and strength in times of recession as they have a very simple decision and a great capacity to adapt to market changes;

e. Relationships of these firms are less formalized by reducing bureaucratic practices in order to eliminate the phenomenon of losing the nature of human relations, forming a closer link between individual and collective efforts, etc.

Management Control System consideration (opinion) about SMEs differ one another. For large companies, SMEs represent the world from which they came and where competition will occur tomorrow. For individuals, SMEs are often a first step towards world entrepreneurs. For economy, SMEs are launched assembly of new ideas and new products that accelerate growth based on more efficient use of resources. In the EU, but also in most developed countries in Europe notes that small and medium share holders in companies, represent the backbone of the European economy and in these conditions leading to the development of the European Charter for Small and Medium Enterprises (2000) adopted by Council Business and accepted by the European Council in Feira (Portugal) based on the following directions:

a. Education and training for entrepreneurs;

b. Initiation of cheaper and faster business; 
c. Development of legislation and better regulation;

d. Providing the necessary qualifications;

e. Improving online access;

f. More determined application of competition rules;

g. Create fiscal and financial reforms;

h. Strengthening the technological capacity of small enterprises;

i. $\quad$ Developing a stronger and more effective representation of small enterprises' interests at national and EU level.

SMEs of Romanian economy, which was deeply affected by economic and financial crisis, continues to exist and to take tough measures to cut costs through strategy of layoffs, wage cuts strategy or reduce administrative costs. In this economical and social situation to maintain afloat the managers must intervene and demonstrate management skills by identifying the most important indicators that help businesses achieve the objectives and management control to intervene in decision making.

The ability of management control to create or added value and influencing stakeholders to practice concrete actions to reduce costs derived from the exploitation costs. By management control System, manager must understand a process attached, on the one hand, to reduce costs, on the other hand, to reallocation of saved resources. So, value creation targets both cost reduction and development activities through organizational changes. The concept of "management control" is a new concept based on a different model of the classic and unquestionably detach from what some authors call it "creative accounting". Creative accounting is used when managers apply to leeway available in the choice of accounting options for changing the presentation and content of the final financial reports. In this sense, creativity appeals to the subjectivity inherent in the construction of models accounting choices and not organizational actions. Creativity lies in accounting measurement and representation in the game and not in concrete actions aimed at the organizational context. However, creating value based on potential earnings converted to reorganization activities and performance by eliminating inefficiency is a tool for cost reduction, increases the value of organizational functions.

\section{CONCLUSION}

MCS is an important function that must be practiced by SMEs. Most researches have shown that good control leads to greater organizational effectiveness. To ensure that business environment is fluid, dynamic and competitive hence MCS is a fundamental requirement. The effectiveness of such control system will depend on application of control measures to monitor and evaluate the progress of the business activities. Management control process acts as a financial and economic knowledge of the company image and represented for the company's management as a guide for work in progress and company future strategy.

Several researches should undertake to emphasis the unresolved questions on the importance of MCS in SMEs. It is not clear what role MCS can play to bring 
intended strategies to realization, or whether MCS can minimize the disruption caused by strategic change (especially when those changes are spread over a considerable period of time). Research could be undertaken to explore whether the role and composition of MCS change as a SMEs matures. The significance of resource sharing between SBUs for the design of MCS under different strategies should also be highlight in more detail, particularly concerning the reliance on either behavior or outcome controls.

\section{References}

Anthony, R. N. (1965). Planning and Control Systems: Framework for Analysis. Boston: Graduate School of Business Administration, Harvard University.

Anthony, R., Dearden, J., \& Bedford, N. M. (1989). Management Control Systems (6th ed). Homewood, III: Irwin.

Accounting, Organizations and Society (1985) pp. 35-50. Goold, M. \&Quinn, J. J., The Paradox of Strategic Controls, Strategic Management Journal (1990) pp. 43-57.

Accounting Education Change Commission. (1990). Objectives of Education for Accountants: Position Statement Number One. Issues in Accounting Education, 5(2), 307-312.

Adegite, E. O. (2010). Accounting, Accountability and National Development. The Nigerian Accountant, Jan/ Mar, (43.1).

Agbiogwu, A. (2010) Accounting Skills Necessary for Successful Entrepreneurship. International Journal of Vocational Studies CCSP, 1(1).

Akande, O.O. (2011). Accounting Skills As a Performance Actor For Small Business in Nigeria. Journal of Emerging Trends in Economics and Management Studies (JETEMs), 2(5). Oyo state.

Bouquin, H. (1994). Les Fondements du Contrôle de Gestion, Que sais-je?, PUF.

Boisselier, P. (1999). Contrôle de gestion, Editions Vuibert, Paris.

Bouquin, H. (2008). Le contrôle de gestion, 8eme edition, Presses Universitaires de France, Paris.

Carta europeană pentru întreprinderi mici şi mijlocii, iunie 2000, aprobată de Consiliul General pentru Afaceri şi acceptată de Consiliul European de la Feira (Portugalia) 19/20 iunie 2000

Dent, J, F. (2000). Strategy, Organisation and Control: Some Possibilities for Accounting Research, Accounting, Organizations and Society, 3-24.

Dekeng, S.B. (2014): Accounting Information System (AIS): Alignment and NonFinancial Performance in Small Firms. International Journal of Computer Networks (IJCN), 6(2).

Donelly, J. A., Gibson, J. L., \& Ivancerich, J. M. (1995). Fundamental of Management. U.S:Irwin Publishers, 288.

Emmanuel, D., Otley, D., \& Merchant, K. (1990). Accounting for Management Control (2nd ed). London: Chapman and Hall.

Essien, O. E. (2001). The Role of Development Financial Institutions (DFIs) in the Financing of Small Scale Industries. Bullion, 25(3), 3-6.

Evbodahe, J. I (2009). Global Trends in The Accountancy Profession, in The Nigerian Accountant, Oct/ Dec, $(42,4)$. 
Flamholtz, E. G. (1983). Accounting, Budgeting and Control Systems in Their Organizational Context: Theoretical and Empirical Perspectives, Accounting, Organizations and Society, 153-174.

Flamholtz, E. G., Das, T. K., \& Tsui, A. (985). Toward an Integrative Framework of Organizational Control, Accounting, Organizations and Society, 35-50.

Govindarajan, V., \& Gupta, A. K. (1985). Linking Control Systems to Business Unit Strategy: Impact on Performance, Accounting, Organizations and Society, 51-66.

Govindarajan, V., (1988). A Contingency Approach to Strategy Implementation at the Business-Unit Level: Integrating Administrative Mechanisms with Strategy. Academy of Management Journal, 828-853.

Glueck, W. F. (1981). Management, Hindsdale Illinois, Dryden Press.

Hopwood, A. G. (1976). Accounting and Human Behavior. Englewood Cliffs, NJ: Prentice-Hall.

Iacob C. (1999). Controlul de gestiune la nivelul firmei, Editura Tribuna Economică, Bucureşti.

Jasra, J.M., Asifkhan, M., Hunjra, A.I., Rehman, R.A., \& IAzam, R. (2011). Determinants of Business Success of Small and Medium Enterprises. International Journal of Business and Social Science, 2(20), 274-280.

Karagiorgos, T., Drogalas, G., Gotzamanis., \& Tampakoudis, I. (2009). The Contribution of Internal Auditing to Management. International Journal of Management Research and Technology, 3(2), Serials Publications, 417-427.

Kaplan, R.S. (1984). The Evolution of Management Accounting. The Acccounting Review, 59(3).

Merchant, K. A. (1985a). Control in Business Orgunizutfons. Boston: Pitman.

Memba, S.F., Gakure W.R., \& Karanja,K. (2011). Venture Capital, Its Impact on Growth of Small and Medium Enterprises in Kenya. University Press.

Melodi, G. O. (1995). A Survey of Inventory Control Practices of Nigerian Manufacturing Firms. Journal of Management, 7(1).

Nnamma, O. J. (2001). Financing Small Scale Business Under The New CBN Directives and The Likely Impact on Industrial Growth of Nigerian Economy. Bullion, 25(3).

Nwankwo, B.C., etal. (2012). Philosophy and Rationale for Effective Organisation Security in Nigerian Local Government Councils. Management Science and Engineering, 6(2), 111-119. www.cscanada.net; www.cscanada.org

Nyakundi, D.O., Nyamita, M.O., \& Tinega, T.M. (2014). Effect of Internal Control Systems on Financial Performance of Small and Medium Scale Business. International Journal of Small Business, 3(1).

Otley, D. T., \& Berry, A. J. (1980). Control, Organisation and Accounting, Accounting, Organizations and Society, 231-246.

Otley, D. T. (1994). Management Control in Contemporary Organizations: Towards a Wider Framework, Management Accounting Research, 289-299.

Ouchi, W. G. (1977). The Relationship between Organizational Structures and Organizational Control. Administrative Science Quarterly, 95-1 12.

Ouchi, W. G. (1979). A Conceptual Framework For The Design of Organizational Control Mechanisms. Management Science, 833-849. 
Samson, D. A., Ianglield-Smith, K. M., \& McBride, P. M. (1991). The Alignment of Management Accounting with Manufacturing Priorities: A Strategic Perspective. The Australian Accounting Review, 29-40.

Simons, R. (1987a). Accounting Control Systems and Business Strategy: An Empirical Analysis, Accounting, Organfzatfons and Socfety, 357-374.

Simons, R. (1995). Levers of Control. Cambridge, MA: Harvard Business School Press.

Simons, R.(1990). The Role of Management Control Systems in Creating Competitive Advantage: New Perspectives, Accounting, Organizations and Society, 127- 143.

Siwangaza, L., Smit, Y., Bruwer, J., \& Ukpere, W.I. (2014). The Status of Internal Controls in Fast Moving Small Medium and Micro Consumer Goods Enterprises within the Cape Peninsula. Mediterranean Journal of Social Sciences, 5(10).

Sule. (1996). Small Scale Industries in Nigeria: Concepts, Appraisal of Government Policies and Suggested Solution to Identified Problems. Economic and Financial Review, 24 (4).

Wiliam., \& David B. (2004). Effectiveness of Internal Control Systems. eChartech of the Institute of Chartered Accountants in England and Wales.

http://www.worldbank.org/en/topic/financialsector/brief/smes-finance 